\title{
BIMBINGAN KELOMPOK TERHADAP INTERAKSI SOSIAL ANAK BINAAN DI LEMBAGA PEMASYARAKATAN KELAS II A CURUP KABUPATEN REJANG LEBONG
}

\author{
Amalia Sari, Hadiwinarto, Syahriman \\ Prodi Bimbingan dan Konseling Fakultas Keguruan dan Ilmu Pendidikan \\ Universitas Bengkulu \\ ict1amaliasari@gmail.com, hadiwin@unib.ac.id, syahriman@unib.ac.id
}

\begin{abstract}
ABSTRAK
Penelitian ini bertujuan untuk mendeskripsikan pengaruh layanan bimbingan kelompok terhadap interaksi sosial anak binaan di Lapas Klas II A Curup. Penelitian ini adalah pra eksperiment pretest-posttest control group desaign. Subjek penelitian sebanyak 20 orang yang dibagi menjadi 2 kelompok yaitu 10 orang kelompok eksperiment dan 10 orang kelompok kontrol, menggunakan teknik purposive sampling. Teknik pengumpulan data menggunakan angket. Hasil penelitian menunjukkan peningkatan yang signifikan dalam interaksi sosial pada anak binaan setelah diberikan layanan bimbingan kelompok dengan rata-rata peningkatan skor sebesar 59,2. Hasil perhitungan uji Wilcoxon dengan nilai z 2,807 dengan taraf signifikansi $0,005<0,05$. Artinya layanan bimbingan kelompok dapat mempengaruhi interaksi sosial anak binaan.
\end{abstract}

Kata kunci: interaksi sosial, bimbingan kelompok

\section{THE EFFEC OF GROUP COUNSELING SERVICES TOWARD SOCIAL INTERACTION OF CHILD CUSTODY AT PENITENTIARY CLASS II A CURUP REJANG LEBONG}

\begin{abstract}
The purpose of this study is to describe the effect of group counseling services toward social interaction of child custody at Penitentiary class A II Curup, Rejang Lebong. This study was experiment pretest-posttest control group design. Subject of this study were 20 who divided into 2 groups; 10 subjects as experiment group and 10 subjects ass control group, which used purposive sampling technique. Data colelected by questionnaire of social interaction. The result obtained from this study was the increasing of social interaction in the child custody after being given group counseling services with the average score increase of 59,2. This is shown from the calculation of Wilcoxon test with the value of $z-2,807$ with significant $0.005<0.05$. it means that group counseling services can influence social interaction of child custody.
\end{abstract}

Keywords: social interaction, group counseling 


\section{Pendahuluan}

Guru merupakan tenaga pendidik, begitu juga dengan konselor sekolah adalah seorang pendidik dengan upaya pendidikannya yaitu konseling (Syahriman, 2013:16). Undang-undang Nomor 20 Tahun 2003 tentang system Pendidikan pada Pasal 1 butir 6 menyebutkan: "Pendidik adalah tenaga kependidikan yang berkualifikasi sebagai guru, dosen, konselor, pamong belajar, widyaswara, tutor, instruktur, fasilitator, dan sebutan yang sesuai dengan kekhususannya, serta berpartisipasi dalam menyelenggaraan pendidikan."

(http://sindikker.dikti.go.id/)

Pemberian layanan bimbingan dan konseling tidak hanya dilakukan di lembaga pendidikan saja, namun layanan bimbingan dan konseling diselenggarakan pada lembaga-lembaga lainnya seperti Lembaga Pemasyarakatan (Lapas). Sebagaimana Asmarawati, Tina (2014:35) menyebutkan bahwa pada UU RI Nomor 12 Tahun 1995 tentang Pemasyarakatan Pasal 14 bahwa narapidana dan anak binaan berhak mendapatkan pendidikan dan pengajaran.

Seseorang yang melanggar hukum tidak hanya dilakukan oleh orang dewasa saja, namun anak pada usia sekolah juga pernah melanggar hukum. Pidana yang dijatuhi pada anak-anak yang melanggar hukum berbeda dengan orang dewasa lainnya. Berdasarkan UU Nomor 11 tahun 2012 tentang Peradilan Pidanan Anak Pasal 69, menyatakan bahwa seorang anak dapat dijatuhi pidana setelah umur 14 tahun, sedangkan anak yang belum berusia 14 tahun hanya dapat dikenai tindakan. (http://perlindungan.kemlu.go.id)

Lapas sejatinya dibangun untuk membina masyarakat atau anak binaan yang mengalami permasalahan terhadap hukum. Dengan adanya Lapas, masyarakat berharap bagi mereka yang bermasalah dengan hukum dapat dibina dan apabila keluar mereka bisa berinteraksi dan bersosialisasi kembali kepada masyarakat seperti pada umumnya. Jika di Lapas ini terjadi pertikaian atau kerusuhan sesama narapidana dan anak binaan, maka pembinaan tidak berjalan dengan semestinya.

Interaksi sosial menurut $\mathrm{H}$. Bonner (dalam Ahmadi, 2009:49) adalah suatu hubungan antara individu atau lebih, di mana kelakuan individu yang satu mempengaruhi, mengubah, atau memperbaiki kelakuan individu yang lainnya atau sebaliknya.

Interaksi sosial bisa terjadi dimana saja begitu pula di Lembaga Pemasyarakatan. Kemampuan interaksi sosial antar narapida, anak binaan, narapidana dengan petugas, anak binaan 
dengan petugas, anak binaan dengan narapidana lainnya, dengan pengunjung tidaklah sama. Anak binaan yang mempunyai kemampuan interaksi sosial yang tinggi akan mudah dapat menyesuaikan diri dengan lingkungannya dan tidak akan mengalami hambatan dalam bergaul dengan orang lain. Adapun bentuk interaksi sosial menurut Syarbani dan Rusdiyanto (2013:28) yaitu kerjasama, persaingan, pertikaian, dan akomodasi.

Selama menjalani hukuman di dalam Lembaga Pemasyarakatan kerap sekali mengalami kerusuhan dan pertikaian seperti berkelahi. Kerusuhan atau pertikaian ini tidak hanya antar narapidana dewasa saja, bahkan pada anak binaan kerap sekali terjadi di beberapa Lapas di Indonesia, seperti di Lapas Klas II A Curup. Pada tanggal 18 Maret 2016 terjadi pertikaian antara anak binaan yang berupa pengeroyokan terhadap anak binaan yang baru masuk (berdasarkan pengamatan selama PLBK). Selain pembulian, pernah terjadi tindak kekerasan sesama antar anak binaan, sehingga membuat korban babak belur dan bahkan ada yang bersembunyi di dalam selokan Lapas karena tidak berani untuk masuk ke dalam selnya. Pada hari Jumat tanggal 14 April 2016 terjadi kerusuhan di Lapas Curup yang melibatkan anak binaan melempar batu ke ruang kalapas. (Radar Pat Petulai, diupload pada 15 April 2016)

Beragam faktor menjadi pendorong tindak kerusuhan dan pertikaian yang disebabkan oleh narapidana, seperti kesalahpahaman antara anak binaan dengan petugas Lapas, kurangnya pemahaman anak binaan terhadap informasi yang disampaikan oleh pihak Lapas, adanya senioritas tahanan, kebiasaan menyalurkan emosi dengan kekerasan. Berbagai penyebab tersebut dapat membuat interaksi sosial yang dilakukan anak binaan dengan lingkungannya menjadi tidak harmonis. Selain itu, pembinaan yang kurang efektif dapat menjadi penyebab terjadinya pertikaian antara anak binaan, di mana anak binaan tidak mendapatkan bimbingan secara optimal.

Banyak sekali strategi layanan bimbingan dan konseling untuk menyelesaikan permasalahan interaksi sosial. Oleh karena itu salah satu strategi yang dapat digunakan untuk permasalahan ini adalah bimbingan kelompok. Menurut Prayitno (2004:3) bimbingan kelompok yang menggunakan dinamika kelompok yang intensif, dengan pembahasan topiktopik, mendorong pengembangan perasaan, pikiran, persepsi, wawasan dan sikap yang menunjang diwujudkannya tingkah laku yang lebih efektif dan berkembangnya 
kemampuan besosialiasasi khususnya peserta layanan.

Penelitian ini bertujuan untuk melihat pengaruh layanan bimbingan kelompok terhadap interaksi sosial anak binaan di Lapas Klass II A Curup.

\section{Metode Penelitian}

Peneliti menggunakan desain PraEksperimentalpre-test and post-test control group design karena penelitian ini melibatkan dua kelompok subjek, satu kelompok diberikan treatment (kelompok eksperimen) dan kelompok satunya tidak diberikan treatment (kelompok kontrol). Subjek Penelitian ini adalah anak binaan di Lapas Klas II A Curup yang berjumlah 30 orang. Namun yang akan diberikan treatmen atau layanan bimbingan kelompok sebanyak 10 orang anak binaan. Teknik pengambilan sampel pada penelitian menggunakan Nonprobability Sampling atau sampel tidak berpeluang dengan teknik Purposive Sampling.

\section{Hasil dan Pembahasan}

Sebelum melaksanakan layanan bimbingan kelompok yang diberikan kepada 10 orang sampel kelompok eksperimen. Peneliti terlebih dahulu mengklasifikasikan skor sampel pada instrument angket. Dapat dilihat pada tabel di bawah ini:
Tabel 1.

Distribusi Skor Interaksi Sosial Anak Binaan di Lapas Klas II A Curup

\begin{tabular}{|c|c|c|c|}
\hline Interval Skor & kategori & Frekuensi & Presentase \\
\hline$\geq 131,3$ & $\begin{array}{l}\text { Sangat } \\
\text { Tinggi }\end{array}$ & 1 & $3 \%$ \\
\hline $102,2-131,2$ & Tinggi & 8 & $27 \%$ \\
\hline $76,5-102,1$ & Sedang & 5 & $17 \%$ \\
\hline $43,8-76,4$ & Rendah & 16 & $53 \%$ \\
\hline$\leq 43,7$ & $\begin{array}{l}\text { Sangat } \\
\text { Rendah }\end{array}$ & 0 & $0 \%$ \\
\hline \multicolumn{2}{|c|}{ Jumlah } & 30 & $100 \%$ \\
\hline
\end{tabular}

Tabel 2.

Perbandingan Pretest dan Posttest Interaksi Sosial Anak Binaan

\begin{tabular}{lllllll}
\hline & Responden & $\begin{array}{l}\text { Skor } \\
\text { Pretest }\end{array}$ & K & $\begin{array}{l}\text { Skor } \\
\text { Posttest }\end{array}$ & K & $\begin{array}{l}\text { Skor } \\
\text { Peningkatan }\end{array}$ \\
\hline Jumlah & 10 orang & 744 & & 1336 & & 592 \\
\hline Mean & & 74,4 & R & 133,6 & ST & 59,2 \\
\hline
\end{tabular}

Berdasarkan tabel di atas dapat disimpulkan bahwa peningkatan skor interaksi sosial yang diperoleh dari 10 orang anak binaan sebelum dan sesudah mendapatkan layanan bimbingan kelompok sebesar 592 dengan skor rata-rata 59,2.

Tabel 3.

Perbandingan Pretest dan Posttest Interaksi Sosial Anak Binaan

\begin{tabular}{lllll}
\hline & Subyek & $\begin{array}{l}\text { Skor } \\
\text { Pretes }\end{array}$ & $\begin{array}{l}\text { Skor } \\
\text { Posttes }\end{array}$ & $\begin{array}{l}\text { Skor } \\
\text { Peningkatan }\end{array}$ \\
\hline Jumlah & 10 & 743 & 107,8 & 335 \\
\hline Mean & 74,3 & 107,8 & 33,5 \\
\hline
\end{tabular}

Pada Tabel di atas dapat disimpulkan bahwa peningkatan skor interaksi sosial yang diperoleh dari 10 kelompok kontrol yang tidak diberikan layanan bimbingan kelompok berupa pre-test dan post-test sebesar 335 dengan skor rata-rata 33,5. 
Uji validitas dilakukan oleh para ahli dengan menggunakan skala sebelas dan uji realibitas dengan menggunakan SPSS 16.0 dan manual. Berdasarkan uji validitas angket diperoleh hasil bahwa angket interaksi sosial yang terdiri dari 50 item pernyataan, didapatkan 15 item yang dinyatakan gugur dan 35 item yang dinyatakan valid.

Sedangkan hasil analisis uji reabilitas dapat dilihat pada tabel di bawah ini:

Table 4.

Uji Reliabilitas

\begin{tabular}{ll}
\hline Cronbach's Alpha & N of Items \\
\hline .937 & 35 \\
\hline
\end{tabular}

Tabel menunjukkan Cronbach's Alpha sebesar 0,937 sehingga instrument tersebut memiliki realibitas sempurna, karena menurut Azwar (2007:83) bahwa suatu alat ukur akan memiliki koefisien realibitas yang tinggi jika semakin mendekati angka 1,00.

Hipotesis dalam penelitian ini adalah menguji pengaruh layanan bimbingan kelompok terhadap interaksi sosial anak binaan di Lapas Klas II A Curup Kabupaten Rejang Lebong. Maka untuk menguji hipotesis tersebut penelitian menggunakan metode analisis data yang statistic non parametric dengan menggunakan rumus Wilcoxon Matched Pairs. Cara menggambil keputusan hipotesis atau $\mathrm{H}_{\mathrm{a}}$ diterima adalah jika nilai $\mathrm{z}$ bernilai negative dan uji nilai Sig. (2tailed) $<0,05$ berarti adanya peningkatan dari sebelum diberikan layanan bimbingan kelompok. Apabila nilai $\mathrm{z}$ dan nilai uji Sig. (2tailed) $>0,05$ maka $\mathrm{H}_{\mathrm{a}}$ ditolak.

Hipotesis penilitian sebagai berikut:

$\mathrm{H}_{\mathrm{a}}$ : Layanan bimbingan Kelompok efektif terhadap interaksi sosial anak binaan di Lapas Klas II A Curup.

Hasil analisis uji Wilcoxon pada kelompok eksperimen dapat dilihat dalam perhitungan pada tabel di bawah ini:

Tabel 5.

Tabel Kerja Uji Wilcoxon Kelompok Eksperimen

\begin{tabular}{ll} 
& pretest - posttest \\
\hline $\mathbf{Z}$ & $-2.807^{\mathrm{a}}$ \\
\hline Asymp. Sig. (2-tailed) & .005 \\
\hline
\end{tabular}

Hasil perhitungan pada table untuk uji Wilcoxon, dapat dilihat bahwa taraf signifikan (2tailed) adalah 0,005 yang berarti nilai signifikan $0,005<0,05$. Berdasarkan kriteria penerimaan dan penolakan hipotesis maka $\mathrm{H}_{\mathrm{a}}$ diterima dan $\mathrm{H}_{\mathrm{o}}$ ditolak. Sehingga diperoleh hasil bahwa layanan bimbingan kelompok efektif terhadap interaksi sosial anak binaan di Lapas Klas II A Curup. Sedangkan nilai uji $\mathrm{z}$ negative $(-2,807)$ menunjukkan bahwa adanya peningkatan interaksi sosial anak binaan setelah diberikan layanan bimbingan kelompok. Pengaruh layanan bimbingan 
kelompok juga dapat dilihat dari perbedaan rata-rata skor pre-test dan post-test pada kelompok eksperimen yaitu 74,4 meningkat menjadi 133,6.

Sedangkan pada kelompok kontrol juga terjadi peningkatan skor pre-test dan post-test. Tetapi, peningkatan pada kelompok kontrol tidak sama dengan peningkatan pada kelompok eksperimen. Peningkatan pada kelompok eksperimen lebih tinggi dibandingkan dengan kelompok kontrol.

Rata-rata skor pretest kelompok eksperimen sebesar 74,4 dan skor rata-rata post-test sebesar 133,6 sehingga terjadi peningkatan sebesar 59,2. Lebih tinggi dibandingkan dengan kelompok kontrol, yaitu skor rata-rata pretest sebesar 74,3 dan skor rata-rata post-test sebesar 107,8 sehingga terjadi peningkatan skor sebesar 33,5 .

Nilai Sig (2 tailed) pada posttest antara kelompok eksperimen dan kelompok kontrol menunjukkan sebesar 0,005 yang berarti nilai signifikan dimana 0,005 $<0,05$. Dengan demikian terdapat perbedaan antara nilai posttest kelompok eksperimen dan kelompok kontol. Begitu juga dengan penyebab terjadinya peningkatan pada kedua kelompok.

Interaksi sosial sampel eksperimen sebelum mendapatkan layanan bimbingan kelompok termasuk pada kategori rendah. Hal ini ditunjukkan pada skor rata-rata pretest yaitu 74,4. Hal ini juga ditunjukkan pada fakta yang terjadi di Lapas Klas II A Curup, dimana anak binaan terlibat pada kerusuhan yang terjadi di Lapas bahkan pertikaian sesama anak binaan itu sendiri.

Selama pelaksanaan layanan bimbingan kelompok pada 10 orang sampel mengalami peningkatan interaksi sosial. Pada kondisi awal sebelum mendapatkan layanan bimbingan kelompok 10 orang anak binaan terdiri dari 8 orang kategori rendah dan 2 orang dengan kategori sedang. Pada kondisi setelah mendapatkan layanan bimbingan kelompok meningkat menjadi 7 orang kategori sangat tinggi dan 3 orang kategori tinggi. Rata-rata skor peningkatan pada kelompok sampel sebesar 59,2. Sedangkan pada kelompok kontrol yang berjumlah 10 orang tidak diberikan treatment berupa layanan bimbingan kelompok. Kondisi awal pada saat pre-test terdiri dari 8 orang kategori rendah dan 2 orang kategori sedang. Lalu pada saat diberikan post-test mengalami peningkatan menjadi 7 orang kategori tinggi dan 3 orang kategori sedang. Rata-rata skor peningkatan pada kelompok kontrol sebesar 33,5.

Keberhasilan ini disebabkan karena pada saat proses pelaksanaan anggota kelompok sangat antusias dalam pelaksanaan layanan 
bimbingan kelompok, anggota kelompok aktif dalam berpendapat, anggota kelompok dapat memahami topik yang dibahas. Anggota kelompok dapat memahami topik yang berkaitan dengan peningkatan interaksi sosial. Topik-topik tersebut yaitu memahami hubungan sosial di lingkungan sekitar, konflik dan pertentangan, memahami teman, menjalin kerjasama dan cara berteman yang baik. Ketika anggota kelompok dapat memahami topik yang dibahas dan menerapkan dalam kehidupan sehari-harinya, maka secara tidak langsung interaksi sosial yang dimiliki anggota kelompok meningkat.

Sebagaimana menurut Tohirin (2001: 172) secara umum tujuan bimbingan kelompok adalah untuk pengembangan kemampuan bersosialisasi, khususnya kemampuan berkomunikasi peserta layanan.Kegiatan layanan bimbingan kelompok yang diberikan menggunakan kelompok tugas, hal ini lah yang paling utama sehingga terarah apa yang menjadi tujuan pada penelitian ini, dari topik-topik yang dibahas merupakan pengembangan dari aspek-aspek interaksi sosial, dari pertemuan pertama hingga pertemuan terakhir merupakan rangkaian satu kesatuan yang saling berkaitan dari setiap topik yang dibahas, sehingga ketika mengikuti kegiatan yaitu layanan bimbingan kelompok dengan baik, maka akan terjadi proses perubahan yang akan dialami oleh anak binaan secara alami terutama pada proses hubungan sosial ataupun interaksi sosial. Sebagaimana H. Bonner(dalam Ahmadi, 2009: 49) menyatakan bahwa interaksi sosial adalah suatu hubungan antara individu atau lebih, dimana kelakuan individu yang satu mempengaruhi, mengubah, atau memperbaiki kelakuan individu yang lain atau sebaliknya.

Peningkatan interaksi sosial pada kelompok kontrol disebabkan karena angket yang diberikan pada pre-test dan post-test sama, sehingga anak binaan dapat mengetahui pola yang jawaban yang diinginkan. Selain itu juga dapat disebabkan pada hubungan atau interaksi sosial yang saling mempengaruhi antara anak binaan yang mendapatkan layanan bimbingan kelompok dan anak binaan yang tidak mendapatkan layanan bimbingan kelompok. hal ini dilihat ketika anak binaan yang mengikuti layanan bimbingan kelompok mengajarkan teman yang lain mengaji.

Hal ini diperkuat dengan, Walgito (2003:57) "Interaksi sosial adalah hubungan antara individu satu dengan individu lain, individu satu dapat mempengaruhi individu lain atau sebaliknya". 
Selain terjadinya hubungan yang saling mempengaruhi, peningkatan pada kelompok kontrol dapat disebabkan oleh faktor imitasi, yang mana anak binaan meniru seseorang baik itu penampilan, perilaku, cara berbica ataupun dalam menyelesaikan masalah. Begitu juga menurut Ahmadi (2009:52) menyatakan bahwa Ada beberapa faktor yang mendasari terjadinya interaksi sosial, yaitu faktor imitasi, sugesti, identifikasi, simpati dan ajaran evolusionisme.

Berdasarkan hasil pelaksanaan layanan bimbingan kelompok, kemampuan interaksi sosial anak binaan di Lapas Klas II A Curup dapat ditingkatakan melalui layanan bimbingan kelompok. Hal ini dibuktikan adanya perubahan interaksi sosial anggota kelompok pada saat kegiatan bimbingan kelompok berlangsung maupun saat di luar kegiatan. RJ pada saat awal kegiatan berlangsung sering menunjukkan perilaku mengancam dan dissosiatif, $\mathrm{Fb}$ dan Sp malu-malu saat mengungkapkan pendapatnya dan pendiam, mengalami perubahan. Terjadi perbedaan kemampuan interaksi sosial anak binaan di Lapas Klas II A curup yang meningkat sebelum dan sesudah mendapatkan layanan bimbingan kelompok. Sebelum diberikan tindakan berupa layanan bimbingan kelompok terdapat anak binaan yang interaksi sosial yang rendah. Namun setelah mendapatkan tindakan berupa layanan bimbingan kelompok terjadi peningkatan interaksi sosial anak binaan di Lapas Klas II A Curup. Walaupun interaksi sosial anak binaan pada kelompok kontrol meningkat namun peningkatan yang dialami kelompok kontrol tidak terlalu tinggi sebagaimana pada kelompok eksperimen.

Penelitian ini akan lebih baik jika layanan bimbingan kelompok dilakukan oleh seorang yang sudah ahli atau konselor. Begitu juga pelaksanaan layanan bimbingan kelompok juga akan lebih efektif jika tempat pelaksanaan di lakukan di tempat khusus.

\section{Kesimpulan}

Berdasarkan hasil penelitian dapat disimpulkan bahwa interaksi sosial anak binaan di Lapas Klas II A Curup Kabupaten Rejang Lebong sebelum mendapatkan layanan bimbingan kelompok menunjukkan pada kategori sedang dan rendah. Hal tersebut bermakna bahwa interaksi sosial anak binaan masih kurang menjalani kerjasama dengan teman pada hal positif, serta kurang memahami dan peduli dengan sesama anak binaan lainnya.

Interaksi sosial anak binaan di Lapas Klas II A Curup Kabupaten Rejang Lebong setelah mendapatkan layanan bimbingan 
kelompok menunjukkan pada kategori sangat tinggi. Hal tersebut menunjukkan bahwa tingkat interaksi sosial anak binaan meningkat sangat baik karena mendapatkan perlakukan berupa layanan bimbingan kelompok. Sedangkan pada kelompok kontrol juga terjadi peningkatan interaksi sosial, hal ini dikarenakan terjadinya interaksi sosial yang saling memepengaruhi antara anak binaan yang mendapatkan perlakuan.

Layanan bimbingan kelompok berpengaruh terhadap interaksi sosial anak binaan di Lapas Klas II A Curup Kabupaten Rejang Lebong. Hal ini dibuktikan dengan uji Wilcoxon dengan nilai z, yaitu $-2,807$ dengan signifikan adalah 0,005 yang berarti nilai signifikan $0,005<0,05$.

\section{Daftar Pustaka}

Ahmadi, Abu. 2009. Psikologi Sosial. Jakarta: PT Rineka Cipta

Asmarawati, Tina. 2014. Pidana dan Pemidanaan Dalam Sistem Hukum di Indonesia. Yogyakarta: Deepublish

Azwar, S. 2007. Metode Penelitian. Yogyakarta: Pustaka Pelajar

http://sindikker.dikti.go.id/dok/UU/UU202003-Sisdiknas.pdf.

http://perlindungan.kemlu.go.id/assets/defa ult/portal/images/galeri_hukum/UU_n o_11_th_2012.pdf
Prayitno. 2004. L.1-L.9. Padang. Universitas Negeri Padang

Radar Pat Petulai.2016. Lapas Curup Rusuh, Ruang Kalapas Dihujani Batu. http://www.radarpatpetulainews.com/ 2016/04/lapas-curup-rusuh-ruangkalapas.html. Diunduh 7 februari 2017

Syahriman. 2013. Wawasan Dasar Bimbingan dan Konseling. Bengkulu. Universitas Bengkulu

Syarbani \& Rusdiyanto. 2013. Dasar-dasa Sosiologi. Yogyakarta: Graha Ilmu

Tohirin. 2011. Bimbingan dan Koseling di Sekolah dan Madrasah (Berbasis Integritas. Jakarta: PT Rajagrafindo Persada

Walgito, B. 2008. Psikologi Sosial. Yogyakarta: Andi Offset 